\title{
GAYA DAN STRATEGI BELAJAR BAHASA
}

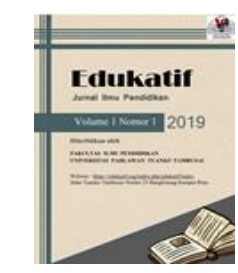

Yayuk Cicilia ${ }^{1}$, Nursalim ${ }^{2}$

Universitas Islam Negeri Sultan Syarif Kasim Riau, Riau, Indonesia ${ }^{1,2}$

e-mail : yayukcicilia89@gmail.com ${ }^{1}$, nursalim@uin-suska.ac.id ${ }^{2}$

\begin{abstract}
Abstrak
Abstrak Penelitian ini bertujuan untuk mengkaji teks, buku-buku dan naskah publikasi mengenai gaya dan strategi belajar bahasa. Di dunia pendidikan, istilah gaya belajar mengacu khusus untuk penglihatan, pendengaran, dan kinestetik. Gaya belajar visual menyangkut penglihatan dan bayangan mental. Gaya belajar pendengaran menunjuk pada pendengaran dan pembicaraan. Gaya belajar kinestetik menunjuk pada gerakan (Emirina, 2009). Hakikatnya strategi pembelajaran bahasa dapat diuraikan mengacu pada keterampilan berbahasa yang dicapai. Oleh karena itu, berbagai strategi berikut dijelaskan dengan mempertimbangkan empat keterampilan berbahasa yakni mendengarkan, membaca, berbicara, dan menulis. Karena kompetensi bahasa adalah keterampilan yang harus dikuasai oleh sesorang, hal ini menjadi dasar yang dikuasai dalam kehidupan bermasyarakat.
\end{abstract}

Kata Kunci: gaya dan strategi belajar, bahasa

\begin{abstract}
This study aims to examine texts, books, and publications on language learning styles and strategies. In the world of education, the term learning style refers specifically to vision, hearing, and Kinesthetic. Visual learning styles involve vision and mental shadow. The auditory learning style refers to hearing and speech. Kinesthetic learning styles refer to movements. The nature of language learning strategies can be described referring to the language skills achieved. Therefore, the following strategies are explained by considering four languages skills, namely listening, reading, speaking, and writing. Because language competence is a skill that must be mastered by someone, this becomes the basis that is mastered in social life.
\end{abstract}

Keywords: learning styles and strategies, language

@Edukasi: Jurnal Ilmu Pendidikan FIP UPTT 2019

$\triangle$ Corresponding author:

Address :

ISSN 2656-8063 (Media Cetak)

Email :

ISSN 2656-8071 (Media Online)

Phone : 


\section{PENDAHULUAN}

Proses pada hakikatnya dinamakan suatu pengolahan atau suatu perencanaan (Strategi Belajar Mengajar Bahasa Indonesia Depdiknas 1997.8). Proses juga dapat diartikan karakteristik semua manusia. Karena semua manusia terlibat dalam proses-proses universal tertentu. Seperti halnya kita memerlukan air, udara dan makanan untuk kelangsungan hidup, begitu pula semua manusia dengan kecerdasan normal menjalani tingkat-tingkat atau tipe-tipe tertentu pembelajaran. ( Prinsip pembelajaran Bahasa $H$. Douglas Brown 2008.126). Sedangkan Gagne berupaya menjelaskan secara global bagaimana orang mengindra, menyaring, menyimpan dan mengingat informasi dalam “delapan jenis' pembelajaran Gagne.

Manusia pada umumnya membangun hubungan-hubungan stimulus-respons dan digerakkan oleh imbalan dan hukuman.Kita semua terlibat dalam asosiasi, penyimpanan makna dan hafalan, transfer, generalisasi, dan interferensi. Semua orang memiliki semacam bakat untuk mempelajari bahasa kedua, yang bisa tergambar dalam proses pembelajaran verbal tertentu. Kita semua mempunyai, dalam proporsi yang berlainan, kemampuan untuk melipatgandakan kecerdasan. Proses adalah karakteristik semua manusia.

Gaya adalah sebuah istilah yang merujuk kepada kecondongan atau kesukaan yang konsisten dan agak tahan lama didalam diri seseorang. Gaya juga dapat diartikan karakteristik umum kerja inte lektual yang berkenaan dengan Anda sebagai individu, dan yang membedakan Anda dari orang lain. Strategi adalah metode khusus untuk mendekati masalah atau tugas, langgam-langgam operasi untuk meraih tujuan tertentu, rancangan tersusun untuk mengendalikan dan memanipulasi tertentu. Oxford \& Ehrman ( 1998, h.8) mendefinikan srategi pembelajaran bahasa kedua sebagai " tindakan, perilaku, langkah, atau teknik spesifik yang dipakai oleh murid untuk meningkatkan pembelajaran mereka sendiri. Desain strategi pembelajaran bahasa menjadi hal yang penting untuk dilaksanakan. Strategi pembelajaran mencakup semua komponen dalam mencapai tujuan. Pembelajaran bahasa Indonesia memiliki tujuan yaitu mencapai kompetensi berbahasa Indonesia.

\section{METODE}

Penelitian ini adalah penelitian kepustakaan atau library research. Penelitian ini bertujuan untuk mengkaji teks, buku-buku dan naskah publikasi mengenai gaya dan strategi belajar bahasa. Kajian ini diambil dari naskah-naskah kepustakaan yang relevan dengan topik penelitian yaitu berkaitan dengan topik yang dibahas. Sumber data yang digunakan adalah data-data hasil penelitian terdahulu yang relevan. Langkahlangkah yang dilakukan diantaranya pengumpulan data pustaka, membaca, mencatat, serta membandingkan literatur untuk kemudian diolah dan menghasilkan kesimpulan. Data yang digunakan merupakan data skunder berasal dari teksbook, jurnal, article ilmiah dan literature review yang berisikan tentang konsep yang sedang dikaji. Penelitian ini merupakan penelitian analisis kebutuhan yang nantinya digunakan sebagai dasar factor personaliti dalam pembelajaran bahasa.

\section{HASIL DAN PEMBAHASAN}

Gaya belajar merupakan sebuah pendekatan yang menjelaskan mengenai bagaimana individu belajar atau cara yang ditempuh oleh masingmasing orang untuk berkonsentrasi pada proses, dan menguasai informasi yang sulit dan baru melalui persepsi yang berbeda. Gaya bersifat individual bagi setiap orang, dan untuk membedakan orang yang satu dengan orang yang lain. Dengan demikian secara umum gaya belajar diasumsikan mengacu pada kepribadian- 
kepribadian, kepercayaan-kepercayaan, pilihanpilihan dan perilaku-perilaku yang digunakan oleh individu untuk membantu dalam suatu situasi yang telah dikondisikan.

Gaya belajar yang digunakan merupakan pengembangkan kinerja dalam pembelajaran. Perlu kita menyadari bagaimana orang yang satu dengan yang lain menyerap dan menggali informasi, dan dapat menjadikan belajar dan berkomunikasi lebih mudah dengan gaya sendiri. Konsentrasi sangat berhubungan dengan gaya belajar. Jika kita mengenali gaya belajar, maka kita dapat mengelola pembelajaran pada kondisi apapun, dimanapun, kapan dan bagaimana cara pembelajaran yang baik dan efektif. Gaya belajar seseorang dipengaruhi oleh faktor alamiah pembawaan dan juga faktor lingkungan. Jadi ada hal-hal tertentu yang tidak dapat diubah dalam diri seseorang bahkan dengan latihan sekalipun. Tapi ada juga hal yang dapat dilatihkan dan disesuaikan dengan lingkungan yang terkadang justru tidak bisa diubah. Gaya belajar siswa sangat mempengaruhi hasil yang di dapat dalam proses belajar.

Menurut Nasution (2013:94) Gaya Belajar ialah cara konsisten yang dilakukan oleh seorang siswa dalam menangkap informasi, cara mengingat, berfikir dan memecahkan soal. Menurut Dunn dan Dunn dalam Nasution (2013:94) menjelaskan bahwa : "Gaya Belajar adalah kumpulan karakteristik pribadi membuat suatu pembelajaran efektif untuk beberapa orang dan tidak efektif untuk orang lain”. Dengan gaya belajar, peserta didik akan lebih mudah memahami pelajaran. Sebagian peserta didik lebih suka pendidik mengajar dengan cara menullis pelajaran di papan tulis lalu memahaminya. Selanjutnya Bobbi Deporter \& Hernacki (2016:109) menambahkan Gaya Belajar adalah suatu kombinasi dan bagaimana seseorang menyerap, dan kemudian mengolah informasi. Berarti gaya belajar berhubungan dengan cara belajar yang paling disukai. Maka, berdasarkan beberapa defenisi diatas, gaya belajar dapat disimpulkan sebagai cara seseorang dalam menerima hasil belajar dengan tingkat penerimaan yang optimal dibandingkan dengan cara yang lain. Setiap orang memiliki gaya belajar masing-masing berbeda.

Pengenalan tentang gaya belajar sangat penting. Bagi guru mengetahui gaya belajar tiap siswa maka guru dapat menerapkan teknik dan strategi yang tepat baik dalam pengembangan diri. Dengan penerapan yang sesuai maka tingkat keberhasilannya lebih tinggi. Seorang siswa juga harus memahami jenis gaya belajarnya. Jadi, ia telah memiliki kemampuan mengenal diri yang lebih baik dan mengetahui kebutuhannya. Pengenalan gaya belajar dapat memberikan pelayanan yang tepat terhadap apa dan bagaimana yang akan dilakukan agar pembelajaran dapat berlangsung optimal. Para ahli di bidang pendidikan mencoba mengembangkan teori mengenai gaya belajar sebagai cara yang tepat untuk mencari jalan agar belajar menjadi hal yang mudah dan menyenangkan. Sebagaimana kita ketahui, belajar membutuhkan konsentrasi.

Skehan (1991 h.288) mengemukakan bahwa gaya pembelajaran sebagai sebuah kecenderungan umum untuk melakukan pemrosesan informasi dalam sebuah cara tertentu. Gaya Belajar merupakan cara atau pendekatan yang berbeda dilakukan oleh seseorang dalam proses pembelajaran (Suparlan, 2004: 31). Di dunia pendidikan, istilah gaya belajar tertuju pada untuk penglihatan, pendengaran, dan kinestetik. Gaya belajar visual terkait penglihatan dan bayangan mental. Gaya belajar pendengaran pada pendengaran dan pembicaraan. Gaya belajar kinestetik menunjuk pada gerakan (Emirina, 2009). 
Jadi gaya belajar adalah suatu kecenderungan yang dimiliki seseorang dalam proses pembelajaran yang merupakan bagian tak terpisahkan dari orang itu. (Anonim, 2009:6) Berdasarkan jenis dan karakteristiknya, gaya belajar bahasa dibagi sebagai berikut:

\section{Gaya Belajar Visual}

Gaya belajar visual (visual learning) mengkususkan pada penglihatan. maknanya, buktibukti konkret harus diperlihatkan terlebih dahulu agar siswa mengerti. Ciri-ciri siswa yang memiliki gaya belajar visual ialah kebutuhan tinggi untuk melihat dan mencerna informasi secara visual sebelum siswa memahaminya. Siswa yang memiliki gaya belajar visual, memahami pelajaran melalui materi bergambar. Selain itu, memiliki kepekaan yang kuat terhadap warna, disamping punya pemahaman yang cukup terhadap masalah artistik. Siswa cenderung mempunyai kendala untuk berdialog secara langsung karena terlalu aktif terhadap suara, maka sulit mengikuti anjuran secara lisan dan sering salah mengartikan kata atau ucapan (Emirina,2009).

Beberapa ciri yang dimiliki siswa yang cenderung memiliki gaya belajar visual, antara lain: selalu terlihat rapi, berbicara dengan cepat, teliti, mementingkan penampilan (baik dalam hal pakaian maupun presentasi), mengingat apa yang dilihat daripada yang didengar, pembaca yang cepat dan tekun, suka membaca daripada dibacakan, suka mencoret-coret tanpa arti/ makna ketika sedang berbicara atau mendengar, sering menjawab pertanyaan dengan singkat, seperti "ya" dan "tidak", lebih suka memperagakan daripada berbicara, lebih mudah mengingat jika dibantu dengan gambar.

Menurut Furgon dalam buku berjudul "Karakteristik Belajar Siswa", secara sederhana guru dapat menyesuaikan cara mengajar dengan gaya belajar siswa visual di antaranya: gunakan simbol-simbol dalam memberikan konsep pada siswa, dorong siswa untuk menguatkan konsepnya dengan menggnakan simbol/ warna, gunakan gambar berwarna, grafik atau tabel sebagai media pembelajaran Furgon (2009).

Ciri-Ciri Yang Menonjol Dari Tipe Gaya Belajar Visual: 1) Senang kerapian dan ketrampilan, 2) Jika berbicara cenderung lebih cepat, 3) Ia suka membuat perencanaan yang matang untuk jangka Panjang, 4) Sangat teliti sampai ke hal-hal yang detail sifatnya, 5) Mementingkan penampilan, baik dalam berpakaian maupun presentasi, 6) Lebih mudah mengingat apa yang di lihat, dari pada yang di dengar, 7) Mengingat sesuatu dengan penggambaran (asosiasi) visual, 8) Ia tidak mudah terganggu dengan keributan saat belajar (bisa membaca dalam keadaan ribut sekali pun), 9) Ia adalah pembaca yang cepat dan tekun, 10) 11) Kadang-kadang suka kehilangan konsentrasi ketika mereka ingin memperhatikan. (Gordon Dryden dan Dr. Jeannette Vos, Revolusi Cara Belajar,2002). Ciri-ciri bahasa tubuh yang menunjukkan seseorang gaya belajar Visual yaitu biasanya duduk tegak dan mengikuti penyaji dengan matanya.

\section{Gaya Belajar Auditorial}

Gaya belajar auditorial mempunyai kemampuan dalam hal menyerap informasi dari pendengaran. Anak yang mempunyai gaya belajar auditori dapat belajar lebih cepat dengan menggunakan diskusi atau mendengarkan apa yang guru katakan (Shota, 2009). Adapun ciri-ciri seseorang yang memiliki gaya belajar auditorial diantaranya: mudah terganggu oleh keributan, menggerakkan bibir membaca dengan keras dan mendengarkan, dapat mengulangi kembali 
dan menirukan nada, merasa kesulitan untuk menulis, tetapi hebat bercerita, berbicara dalam irama yang terpola, biasanya pembicara yang fasih, belajar dengan mendengarkan dan mengingat apa yang didiskusikan daripada yang dilihat, suka berbicara, suka berdiskusi dan menjelaskan sesuatu panjang lebar, dan lebih suka gurauan lisan daripada membaca komik (DePorter dan Hernacki, terjemah Alwiyah, 2009).

Secara sederhana kita dapat menyesuaikan cara mengajar kita dengan gaya belajar siswa, di antaranya: Variasikan vokal saat memberikan penjelasan, seperti intonasi, volume suara, ataupun kecepatannya, gunakan pengulangan konsep yang sudah diberikan, ubahlah konsep ke dalam bentuk irama/ lagu, dan selingi belajar dengan musik atau mendengarkan materi lewat tape recorder.

\section{Ciri-Ciri Yang Menonjol Dari Tipe Gaya} Belajar Auditorial: 1) Saat bekerja sering berbicara pada diri sendiri, 2) Mudah terganggu oleh keributan atau hiruk pikuk disekitarnya, 3) Merasa kesulitan untuk menulis tetapi mudah dalam bercerita, 4) Biasanya ia adalah pembicara yang fasih,, 5) Lebih menyukai musik dari pada seni yang lainnya, 6) Lebih mudah belajar dengan mendengarkan dan mengingat apa yang didiskusikan dari pada yang dilihat, 7) Suka berbicara, berdiskusi, dan menjelaskan sesuatu dengan panjang lebar., 8) Lebih pandai mengeja dengan keras dari pada menuliskannya. (Gordon Dryden dan Dr. Jeannette Vos, Revolusi Cara Belajar,2002), 9) Sering menggerakkan bibir dan mengucapkan tulisan dibuku ketika membaca, 10) Senang membaca dengan keras dan mendengarkan sesuatu.

Ciri-ciri bahasa tubuh yang menunjukkan seseorang gaya belajar Auditorial yaitu sering mengulang dengan lembut kata-kata yang di ucapkan penyaji, atau sering menggunakan kepalanya saat fasilitator menyajikan informasi lisan. Pelajar tipe ini sering "memainkan sebuah kaset dalam kepalanya" saat ia mencoba mengingat informasi. Jadi, mungkin ia akan memandang ke atas saat ia melakukannya.

\section{Gaya Belajar Kinestetik}

Gaya belajar kinestetik ialah aktivitas belajar dengan cara bergerak, bekerja dan menyentuh. Pembelajar tipe ini memiliki keunikan dalam belajar selalu bergerak dan menyentuh. Siswa dengan tipe gaya belajar ini sulit untuk duduk diam berjam-jam karena keinginan mereka untuk beraktifitas dan eklorasi sangatlah kuat.

Ciri-ciri seseorang yang memiliki gaya belajar kinestetik di antaranya: berbicara dengan perlahan, mudah terganggu dengan keributan, selalu berorientasi pada fisik dan banyak bergerak, belajar melalui praktik, menghafal dengan cara berjalan dan melihat, menggunakan jari sebagai petunjuk ketika membaca, banyak menggunakan isyarat tubuh,dan tidak dapat duduk untuk waktu yang lama.

Secara sederhana kita dapat menyesuaikan cara mengajar kita dengan gaya belajar siswa, diantaranya : gunakan selalu alat bantu saat mengajar, agar timbul rasa ingin tahu siswa, saat membimbing secara perseorangan biasakan berdiri/ duduk di samping siswa, buat aturan main agar siswa boleh melakukan banyak gerk di dalam kelas, peragakan konsep, sambil siswa memahami secara bertahap. Dan biasakan berbicara kepada siswa secara pribadi saat di dalam kelas.

Ciri-Ciri Tipe Gaya Belajar Kinestetik: 1) Berbicara dengan perlahan, 2) Menyentuh orang untuk mendapatkan perhatian mereka, 3) Berdiri dekat ketika berbicara dengan orang, 4) Selalu berorientasi dengan sifik dan banyak bergerak, 5) 
Menghafal dengan cara berjalan dan melihat, 6) Menggunakan jari sebagai penunjuk ketika membaca, 7) Banyak menggunakan isyarat tubuh Tidak dapat duduk diam untuk waktu lama, 8)Memungkinkan tulisannya jelek, 9) Ingin melakukan segala sesuatu, 10) Menyukai permainan yang menyibukkan. (Bobby DePorter dan Mike Hernacki, Quantum Learning,2006)

\section{Faktor-Faktor yang mempengaruhi Gaya Belajar}

Gaya belajar yang digunakan merupakan kunci untuk mengembangkan kinerja dalam belajar. Perlu disadari bagaimana orang yang satu dengan yang lain menyerap dan menggali informasi, dan dapat menjadikan belajar dan berkomunikasi lebih mudah dengan gaya sendiri. Sebagian siswa dapat belajar paling baik dengan pencahayaan terang, sedangkan sebagian siswa lain dengan pencahayaan yang suram.

Ada siswa yang belajar paling baik secara berkelompok, sedangkan yang lain memilih belajar dengan adanya figur yang otoriter seperti gutu atau orangtua, yang lain merasa bahwa bekerja sendirilah yang paling efektif bagi mereka. Sebagian orang memerlukan musik sebagai iringan belajar, sedangkan yang lain tidak dapat berkonsentrasi kecuali dalam keadaan sepi. Ada siswa yang memerlukan lingkungan belajar yang teratur dan rapi, tetapi ada yang lebih suka menggelar segala sesuatunya supaya dapat dilihat (Qodriyah, 2011: 27). Ketika belajar siswa perlu berkonsentrasi dengan baik. Untuk bisa berkonsentrasi dengan baik, perlu adanya lingkungan yang medukung belajar siswa. Faktor lingkungan juga dapat mempengaruhi konsentrasi belajar siswa, antara lain:

Tiap siswa mempunyai reaksi yang berbedabeda terhadap suara, ada yang menyukai belajar dengan mendengarkan musik lembut, keras, ataupun menonton televisi. Ada juga yang menyukai belajar dalam suasana sepi dan ada juga yang menyukai belajar dalam suasana ramai dalam kelompok.

Pencahayaan juga faktor yang pengaruhnya kurang dirasakan dibandingkan pengaruh suara.

Tiap siswa juga mempunyai selera yang berbeda-beda. Ada yang suka tempat sejuk, ada juga yang lebih menyukai tempat yang hangat ketika belajar.

Desain belajar ada dua macam, yaitu desaian belajar formal dan desain belajar tidak formal. Sebagai contoh desain formal belajar di meja dengan alat-alatnya, sedangkan belajar tidak formal yaitu dengan belajar santai seperti, duduk di lantai ataupun sambil tiduran (Qodriyah, 2011: 29).

\section{Strategi Pembelajaran Bahasa}

Sejalan dengan tujuan utama pembelajaran Bahasa Indonesia yaitu agar siswa memiliki kemahiran berbahasa diperlukan sebuah alternatif baru yang lebih variatif, aplikatif, dan menarik dalam pengajaran Bahasa Indonesia di sekolah. Pembelajaran yang menarik akan memikat anak didik untuk terus dan betah mempelajari Bahasa Indonesia sebagai bahasa ke-2 setelah bahasa ibu. Apabila siswa sudah tertarik dalam pembelajaran maka akan dengan mudah meningkatkan prestasi siswa dalam bidang bahasa (Ishaq, 2006). Salah satu strategi pembelajaran yang variatif, aplikatif, dan menarik adalah masyarakat belajar (learning community) yang menekankan kepada kerja sama kelompok untuk menyelesaikan sebuah masalah.

Dalam strategi ini, siswa ditempatkan dalam tim belajar beranggotakan $4-5$ orang yang heterogen menurut tingkat prestasi, jenis kelamin, dan suku. Guru menyajikan pelajaran, siswa bekerja dalam tim mereka untuk memastikan seluruh anggota tim telah menguasai pelajaran tersebut. Saat belajar kelompok, siswa saling membantu untuk menuntaskan materi 
yang dipelajari. Guru mamantau dan mengelilingi tiap kelompok untuk melihat adanya kemungkinan siswa yang memerlukan bantuan guru.

Khusus mata pelajaran Bahasa Indonesia, berdasarkan hasil analisis penelitian terhadap rendahnya hasil belajar peserta didik (Trianto: 2008:4), bahwa strategi pembelajaran yang digunakan guru terlalu menekankan pada penguasaan jumlah informasi/konsep belaka. Penumpukan informasi/konsep pada subjek didik dapat saja kurang bermanfaat bahkan tidak bermanfaat sama sekali kalau hal tersebut hanya dikomunikasikan oleh guru kepada subjek didik melalui satu arah seperti menuang air ke dalam sebuah gelas. Tidak dapat disangkal, bahwa konsep merupakan suatu hal yang sangat penting, namun bukan terletak pada konsep itu sendiri tetapi, terletak pada bagaimana konsep itu dipahami oleh subjek didik. Memang penting pemahaman konsep dalam proses belajar mengajar karena sangat mempengaruhi sikap, keputusan, dan cara-cara memecahkan masalah. Kenyataan yang terjadi adalah siswa hanya menghafal konsep dan kurang mampu menggunakan konsep tersebut jika menemui masalah dalam kehidupan nyata yang berhubungan dengan konsep yang dimiliki. Bahkan siswa kurang mampu menentukan masalah dan merumuskannya.

Maka, strategi pembelajaran bahasa dapat diuraikan dengan mengacu kepada keterampilan berbahasa yang dituju. Oleh karena itu, berbagai strategi berikut dijelaskan dengan mempertimbangkan empat keterampilan berbahasa yakni mendengarkan, membaca, berbicara, dan menulis.

Jika melihat kebutuhan masyarakat masa kini, yang mengalami globalisasi di berbagai sendi kehidupannya, pembelajaran bahasa harus diubah. Seperti telah dikemukakan bahwa sejak 1994, kurikulum sekolah dasar dan menengah telah disusun berdasarkan kompetensi. Oleh karena itu, kurikulum pembelajaran bahasa berbasis pada kompetensi, yaitu keempat keterampilan bahasa (mendengarkan, membaca, berbicara, dan menulis), bukan lagi pada tata bahasa dan ilmu bahasa. Masalah pokok dalam pembelajaran bahasa adalah kebutuhan peserta didik untuk memahami dan mengungkapkan diri. Itulah sebabnya, anak-anak yang belajar bahasa di rumah dan di jalan lebih berhasil daripada di kelas. Dengan demikian, sangat penting bagi para guru bahasa untuk mengubah cara berpikirnya sehingga mampu melakukan pembelajaran berbasis kompetensi dan menyusun bahan ajar yang sesuai. Dalam pembelajaran bahasa terdapat beberapa model strategi pembelajaran yang mengacu pada keterampilan mendengarkan. Akan tetapi, dalam pelaksanaan strategi pembelajaran mendengarkan yang disarankan oleh Rost (1991) berikut tidak tertutup kemungkinan melibatkan kegiatankegiatan dalam ruang lingkup keterampilan berbicara dan menulis.

\section{Demonstrasi}

Dalam kegiatan ini, siswa melihat sebuah demonstrasi yang dilakukan oleh guru atau siswa (yang diminta guru) di dalam kelas. Demonstrasi tersebut dapat berupa bagaimana proses membuat telur dadar (jika kondisi memungkinkan) atau membuat secangkir teh manis. Demonstrasi tersebut harus memiliki urutan kegiatan siswa. kemudian mendemonstrasikan kembali kegiatan yang telah mereka saksikan. Siswa menunjukkan pemahaman mereka terhadap kegiatan yang telah disaksikan dan memberikan kesempatan kepada mereka untuk merespons secara verbal.

\section{Cerita Pribadi}

Dalam kegiatan ini, siswa mendengarkan cerita personal guru. Selanjutnya, siswa diberi kesempatan untuk mengajukan beberapa pertanyaan kepada guru tentang cerita yang telah 
didengarnya. Kegiatan ini bertujuan mengembangkan perhatian siswa secara lebih lama terhadap cerita dan menimbulkan interaksi dengan pembicara (guru). Kegiatan ini dapat dilanjutkan dengan meminta siswa membuat rangkuman cerita lalu siswa melaporkan hasil rangkumannya secara lisan.

\section{Wawancara}

Siswa melakukan kegiatan wawancara berdasarkan pertanyaan-pertanyaan (rambu-rambu wawancara) yang telah disediakan. Hal ini bertujuan untuk membantu kelancaran siswa dalam berkomunikasi. Siswa dilatih melakukan wawancara secara berpasangan. Salah seorang siswa menjadi penanya dan lainnya menjadi orang yang diwawancarai. Lalu, siswa bergantian memainkan perannya. Apabila telah memiliki "pengalaman" melakukan kegiatan berwawancara di kelas, siswa dapat melakukan kegiatan secara nyata di luar kelas dengan mewawancarai guru atau kepala sekolah atau bahkan tokoh masyarakat.

\section{Bertelepon}

Dalam kegiatan ini, siswa saling mendengarkan dan menjawab telepon. Kegiatan dilakukan secara berpasangan di dalam kelompok. Dengan cara ini semua siswa mendapat kesempatan melatih diri yang bertujuan mengembangkan kemampuan berkomunikasi. Selain itu, kegiatan bertelepon dapat melatih siswa menyimpulkan kalimatkalimat yang didengarnya.

\section{Bagan Cerita (Story Maps)}

Dalam kegiatan ini, siswa mendengarkan sebuah cerita. Sambil mendengarkan cerita, siswa mengisi bagan-bagan cerita yakni tokoh-tokoh yang ada di dalam cerita, masalah cerita, pemecahan masalah, dan akibat pemecahan masalah. Selanjutnya, kegiatan dapat dilanjutkan dengan meminta siswa memerankan tokoh-tokoh cerita berdasarkan responsnya. Hal ini bertujuan mengembangkan kemampuan siswa dalam mengorganisasi cerita dengan bantuan baganbagan, kemampuan melatih daya ingat, dan kemampuan merespons kembali cerita dengan cara memerankannya.

\section{Survei Kelompok}

Siswa bekerja dalam kelompok-kelompok kecil untuk menyelesaikan survei personal kemudian melaporkannya ke seluruh anggota kelas. Masalah yang menjadi bahan survei misalnya cita-cita teman, keadaan keluarga teman, dan pengalaman temannya. Hal ini bertujuan untuk mengembangkan kemampuan memulai interaksi. Survei kelompok juga mendorong siswa mendengarkan teman sekelas dengan seksama.

\section{Pidato Singkat}

Dalam kegiatan ini, siswa mendengarkan pidato singkat yang diberikan temannya. Siswa yang menjadi pendengar mencatat isi pidato dan memberikan pertanyaan kepada temannya yang berpidato. Hal ini bertujuan mendorong siswa untuk melakukan konfirmasi dan klasifikasi, mengembangkan keterampilan dalam mengidentifikasi informasi yang hilang.

\section{Keterampilan Membaca}

Keterampilan membaca merupakan serangkaian keterampilan yang memiliki peranan yang unik jika dihubungkan dengan kegiatan membaca untuk pemahaman berbagai bidang studi (Diem, Ihsan dan Indrawati, 2003:204). Tujuan membaca adalah untuk mencari informasi yang terdapat dalam teks, baik informasi yang tersurat (fakta) maupun yang tersirat (inferensi). Siswa sering tidak mampu menentukan gagasan atau ide pokok wacana yang dibacanya. Mereka masih bingung dalam 
menentukan mana gagasan pokok dan mana gagasan pendukung. Oleh karena itu, salah satu alternatif model pembelajaran yang dapat dilakukan adalah dengan memanfaatkan pemetaan pikiran (mindmapping). Wycoff (2002:63) mengembangkan pemetaan pikiran sebagai salah satu keterampilan yang paling efektif dalam proses berpikir kreatif.

Sementara itu, Hernowo (2003:119) mengemukakan bahwa teknik pemetaan pikiran dapat mempertajam dan mempertinggi proses pengikatan yang dilakukan. Penggunaan teknik ini akan membuat kegiatan membaca dapat dilaksanakan secara menyenangkan. Pemetaan pikiran dapat memadukan kegiatan otak kiri dan otak kanan secara efektif dan bersinergi.

Dalam kegiatan membaca, selain mendapatkan informasi faktual dan inferensial yang ingin diperoleh butir lain yang tidak kalah pentingnya adalah merangkum atau meringkas wacana yang dibaca. Dalam kompetensi dasar membaca meringkas atau merangkum dapat dijumpai dalam kurikulum 2004 untuk SD ataupun SMP. Oleh karena itu, seorang guru perlu melatih bagaimana menuangkan ide dalam tulisan. Hal itu dapat ditempuh melalui pemetaan pikiran. Ada tujuh langkah strategi dalam pemetaan pikiran yang dikemukakan oleh Hernowo (2003:23-25) yaitu sebagai berikut.

1. Pusat masalah atau ide utama yang akan dipetakan diletakkan di tengah halaman.

2. Ide utama terdiri atas gagasan-gagasan dinyatakan dengan menggunakan katakata kunci.

3. Gagasan-gagasan berupa kata-kata kunci itu dihubungkan ke ide utama yang berada di

4. tengah dengan garis-garis.

5. Apabila gagasan-gagasan tersebut memiliki sub-subgagasan diletakkan berdekatan dengan gagasan yang berkaitan dengan menggunakan spidol atau pensil berwarna yang sama untuk menunjukkan hubungan. Setiap gagasan dikembangkan secara teratur.

\section{Keterampilan Berbicara}

Dalam pembelajaran keterampilan berbicara banyak alternatif yang dapat dipergunakan seperti penggunaan media gambar. Cara lain dapat pula dipergunakan, seperti pemberian skema. Skema dimaksudkan adalah pokok-pokok yang akan dibicarakan itu diskemakan atau dipetakan, seperti yang diterangkan dalam prinsip penggunaan pemetaan konsep dalam pembelajaran membaca. Cara lain yang dapat dipergunakan guru adalah dengan menggunakan sebuah strategi yang disebut dengan "lihat dan katakan" (Bailey dan Savage, 1994:124--125). Langkah-langkah strategi lihat dan ucap yang dapat dilakukan melalui cara sebagai berikut.

1. Guru membagi siswa ke dalam kelompok yang terdiri atas 3-4 orang.

2. Guru membagikan cerita singkat yang dapat dibaca dalam waktu paling lama 5 menit.

3. Siswa mengutarakan cerita di dalam kelompok secara bergantian. Semua siswa harus mendapat giliran berbicara dan lainnya menyimak cerita temannya. Masingmasing siswa mendapat giliran berbicara sebanyak 2 kali.

4. Wakil dari masing-masing kelompok mengutarakan cerita di depan kelas.

5. Guru dan siswa mendiskusikan cerita yang didengar dan mendiskusikan bahasa yang digunakan dalam menyampaikan cerita.

\section{Keterampilan Menulis}

Kegiatan menulis dinilai sebagai kegiatan yang lebih sulit dibandingkan dengan kegiatan berbahasa lainnya. Hedge (1992:3) menyatakan bahwa dalam kegiatan menulis dituntut 
kemampuan kognitif yang tinggi, pengetahuan yang luas, dan kepekaan menulis. Maka, walaupun seseorang telah terampil berbahasa misalnya berbicara belum tentu ia dapat menulis. Walaupun kegiatan menulis merupakan kegiatan yang sulit dan tidak banyak orang yang menguasainya, disadari bahwa menulis itu sendiri sangatlah penting. "Melalui kegiatan menulis, seseorang dapat mengutarakan idenya, perasaannya, dan mempengaruhi serta meyakinkan orang lain" (White dan Arndt, 1994:3).

Pada sisi lain, Hedge (1992:8) menyatakan bahwa keterampilan menulis pada dasarnya diperlukan oleh siswa karena siswa membutuhkannya baik bagi pendidikannya, kehidupan sosialnya, maupun pada kehidupan profesionalnya nanti. Oleh sebab itu, guru seyogyanya melatih siswa menulis seawalawalnya.

Berikut sejumlah strategi alternatif yang ditawarkan oleh Hedge (1992), White dan V. Arndt. (1994), dan Byrne (1998) yang dapat digunakan oleh guru. Disadari bahwa tidak tertutup kemungkinan beberapa kegiatan tidak dapat atau bahkan dapat diterapkan pada usia atau tingkat tertentu.

\section{Mengisi Gelembung-gelembung Ujaran}

Siswa juga harus mengisi gelembung ujaran yang terdapat pada komik. Ujaran-ujaran yang terdapat di dalam komik dihilangkan dengan jalan menghapusnya lalu difotokopi (dengan ujaran yang telah kosong). Tugas siswa mengisi gelembung-gelembung ujaran tersebut berdasarkan responsnya terhadap gambar-gambar tokoh komik yang ada. Kegiatan ini akan menjadi lebih menarik jika gambar-gambar membentuk suatu urutan peristiwa.

\section{Membuat Salinan Nyanyian}

Siswa membuat salinan dialog, lagu, dan puisi. Di samping itu, siswa membuat ilustrasinya.
Kegiatan ini sangat penting. Pada kegiatan ini siswa memperlihatkan imajinasi ketika mengilustrasikan materi ini.

\section{Membuat Daftar}

Dalam kegiatan ini siswa diminta menyusun daftar seperti hal-hal yang ingin mereka makan, negara-negara yang ingin mereka kunjungi, dan binatang yang ingin mereka lihat. Siswa kemudian dapat membedakan aneka pilihan dari daftar yang telah dibuatnya dengan daftar yang dibuat temannya.

\section{Menyusun Informasi}

Pada kegiatan ini siswa harus menulis beberapa kalimat yang menyediakan informasi, misalnya tentang salah satu tokoh di dalam komik. Kegiatan tersebut bisa dibarengi dengan membuat gambar tokoh di dalam komik tersebut.

\section{Menulis Catatan}

Pada kegiatan ini siswa menulis catatan satu sama lain (dan boleh kepada guru) di kelas. Kegiatan ini adalah kegiatan dasar bagi pelajar pemula sebab mereka didorong menulis dengan cepat. Dengan demikian, dalam waktu lebih kurang lima menit mereka dapat mengirim dan menjawab pesan. Jadi, siswa dapat: (a) bertanya sesuatu misalnya kartu gambar dengan teman yang berada di dekatnya; (b) bertanya tentang informasi pribadi; (c) bertanya tentang cerita atau film dan sebagainya.

\section{Menulis Laporan Buku}

Ketika siswa sudah mencapai tahap "pembaca", mereka dapat diminta untuk menulis 2-3 kalimat yang melaporkan buku yang dibacanya. Laporan dapat dilekatkan di belakang buku untuk dibaca oleh siswa yang lain. Siswa yang lain diminta mengomentari laporan buku temannya. 


\section{Menulis Pesan}

Siswa diminta menceritakan pengalamannya dari tempat yang dianggap “asing/aneh" misalnya bulan, dasar laut, dalam balon, dan tengah padang pasir. Siswa diminta menceritakan misalnya bagaimana rasanya ketika ia berada di bulan, bagaimana kondisi bulan, dan bagaiman kehidupan di bulan.

\section{Pesan di Kartu Ultah}

Siswa diminta mengirimkan pesan di kartu ketika kawannya berulang tahun. Penyiapan kartu dapat dilakukan di rumah namun menggambar dan menulis pesan dapat dilakukan di kelas.

\section{Kerja Proyek}

Tugas yang menyenangkan dan bermanfaat bagi siswa yaitu meminta mereka membuat kamus bergambar. Siswa dapat bekerja sendiri atau berkelompok (mereka harus membantu satu sama lain). Karena kamus, mereka akan memerlukan satu buku latihan. Mereka dapat menggambar sendiri atau menggunting gambar dari koran. Tujuan kegiatan ini ialah mereka menulis kata-kata yang menarik perhatian mereka. Mereka menulis kalimat tentang kata-kata yang mereka pilih (bukan definisi). Misalnya, mereka dapat menulis tentang kelinci: nama kelinci, makanan kelinci, umur kelinci, dan tempat tinggal kelinci dengan menempelkan gambar kelinci atau menggambar sendiri kelinci itu.

\section{Menulis Kreatif}

Berdasarkan pengalaman Hedge (1992), banyak siswa menyukai proses menulis kreatif dan siswa menikmati kesempatan untuk menulis lebih kreatif. Termasuk di dalam kegiatan ini adalah menulis puisi dan cerpen.

\section{Write From The Start}

Strategi write from the start merupakan strategi yang dikembangkan oleh Davidson dan Blot (1994). Mereka percaya bahwa siswa dapat menulis seawal-awalnya. Strategi ini dapat memberikan pengalaman dengan berpraktik berbahasa Inggris-Indonesia sejak awal. Siswa akan belajar menulis dengan menulis (students will learn to write by writing). Strategi ini langsung melibatkan siswa ke dalam aktivitas menulis tanpa terlalu memperhitungkan masalah gramatikal dan EYD. Dengan demikian, strategi ini memberikan kesempatan kepada siswa menjadi "penulis." Strategi write from the start menyediakan panduan kontrol dan kesempatan kepada siswa untuk menulis tentang diri mereka sendiri, teman mereka, keluarga dekat mereka, dan ide-ide mereka. Pembelajaran menulis akan lebih efektif jika pembelajaran itu merespons kebutuhan siswa.

\section{Menulis Laporan suatu Peristiwa}

Siswa diminta menulis peristiwa nyata baik lokal, nasional maupun internasional. Siswa diberi kesempatan berperan layaknya seorang reporter surat kabar yang bertugas melaporkan berita.Misalnya, siswa diminta melaporkan pertandingan olah raga yang terjadi baik pada peristiwa lokal, nasional maupun internasional

\section{SIMPULAN}

Maka pada dasarnya, tidak ada strategi pembelajaran yang baik dan buruk, yang ada ialah guru yang baik dan guru yang buruk. Strategi apa pun, sehebat apa pun sebuah strategi, jika dibawakan oleh guru yang tidak dapat memaknai strategi itu secara tepat dan sesuai dengan kondisi 
kelas dan karakteristik siswanya, strategi itu akan kehilangan daya tariknya. Oleh karena itu, diharapkan guru bahasa Indonesia dapat memilih strategi yang sesuai tujuan pembelajaran dan sesuai dengan hakikat belajar bahasa Belajar bahasa sebenarnya ialah belajar bagaimana menggunakan bahasa tersebut baik. Pada dengan aspek pemahaman maupun pada aspek produktif bukan belajar tentang bahasa

\section{DAFTAR PUSTAKA}

Abu ahmadi dan Widodo Supriyono. 2008. Psikologi Belajar.Rineka Cipta : Jakarta.

Azhar Arsyad. 2008. Media Pembelajaran. PT. Raja Grafindo Persada: Jakarta.

Byrne, D. (1998). Teaching writing skills. London: Longman.

Gordon Dryden dan Dr. Jeannette Vos. 2002. Revolusi Belajar (the Learning revolution): Belajar akan efektif kalau anda dalam keadaan Fun. Kaifa : Bandung.

Hastuti P.H., Sri. 1997. Strategi Belajar Mengajar Bahasa Indonesia. Depdiknas: Jakarta.

Hedge, T. (1992). Writing: Resource books for teachers. Alan Maley (Ed.) Oxford: Oxford University Press.

Hernowo,Ed. 2003. Quantum reading. Jakarta: MLC.

Huda, Nuril.1999. Implikasi Kajian Strategi Belajar Bahasa Kedua. Depdikbud: Malang.

Nini Subini. 2012. Mengatasi Kesulitan Belajar Pada Anak. Javalitera : Jogjakarta.

S. Nasition. 2011. Berbagai Pendekatan Dalam Proses Belajar \& Mengajar. Bumi Aksara:Jakarta.

Sukadi. 2008. Progressive Learning. Niaga Qolbun Salim : Bandung.

Uno Hamzah . 2008.Orientasi Baru Dalam Psikologi Pembelajaran. Bumi Aksara:Jakarta. 